\title{
Persepsi Santri Terhadap Eksistensi Penolong Sebaya Berbasis Kearifan Lokal Pesantren
}

\section{Santri's Perception Of The Existence Of Peer Helper Based On The Local Wisdom Of Pesantren}

\author{
Yuliati Hotifah ${ }^{1}$, Irene Maya Simon ${ }^{1}$ \\ 1 Jurusan Bimbingan dan Konseling, Universitas Negeri Malang \\ yuliati.hofiah.fip@um.ac.id
}

\begin{abstract}
Abstrak
Tujuan penelitian ini adalah mengkaji bagaimana persepsi santri terhadap eksistensi penolong sebaya berbasis kearifan lokal pesantren. Eksistensi penolong sebaya tersebut meliputi sikap dan ketrampilan penolong sebaya pesantren serta kualitas layanan penolong sebaya pesantren. Penelitian ini menggunakan metode survey, instrumen pengumpulan datanya menggunakan skala persepsi santri terhadap eksistensi penolong sebaya pesantren yang memenuhi tingkat validitas dan reliabilitas cukup. Populasi penelitian ini adalah santri pondok pesantren Hidayatul Mubtadiin kanigoro Blitar dari berbagai jenjang Mts, MA, SMK dan Salafiyah Tahfidzul Qur'an sebanyak 861 santri. Sedangkan teknik sampling yang digunakan adalah purposive sampling dengan kriteria, yaitu 1) santri remaja yang berusia 13-18, 2) pernah mendapatkan layanan konseling sebaya pesantren dan 3) santri yang mukin di pesantren (bukan santri kalong). Jumlah sampel didapatkan sebanyak 86 santri. Analisis data penelitian ini menggunakan analisis kuantitatif diskriptif dengan teknik prosentase. Hasil penelitian ini menunjukkan bahwa persepsi santri terhadap eksistensi penolong sebaya berbasis pesantren berada pada kategori sedang. Hal ini menunjukkan bahwa sikap dan keterampilan penolong sebaya pesantren masih dipersepsikan secara negative oleh santri. Layanan penolong sebaya pesantren masih belum dilaksanakan secara maksimal sesuai dengan indikator keberhasilan layanan konseling sebaya pesantren. Peningkatan eksistensi penolong sebaya pesantren perlu mendapatkan perhatian yang serius dalam manajemen pengelolaan dan peningkatan SDM penolong sebaya berbasis pesantren. Diharapkan dengan meningkatnya kualitas penolong sebaya pesantren akan berkorelasi positif meningkatkan kepercayaan santri, secara langsung akan berimbas pada proses penyelesaian permasalahan santri.
\end{abstract}

Kata kunci: Persepsi, eksistensi, penolong sebaya

\begin{abstract}
The purpose of this study is to examine how the students perceive the existence of peer counselors based on the local wisdom of pesantren. The existence of peer counselors includes the attitudes and skills of the pesantren peer counselors and the quality of the services of the pesantren peer counselors. This study uses a survey method, the data collection instrument uses a scale of perceptions of santri on the existence of a peer helper that meets sufficient levels of validity and reliability. The population of this study were santri in the Hidayatul Mubtadiin kanigoro Islamic boarding school of Blitar from 861 santri to the Mts, MA, SMK and Salafiyah Tahfidzul Qur'an. While the sampling technique used was purposive sampling with criteria, namely 1) santri adolescents aged 13-18,2) had received counseling services for a number of pesantren and 3) santri who studied at pesantren (not santri kalong). The number of samples was 86 students. Data
\end{abstract}


analysis of this study uses descriptive quantitative analysis with percentage techniques. The results of this study indicate that students' perceptions of the existence of boarding-based peer counselors are in the moderate category. This shows that the attitudes and skills of pesantren peer counselors are still perceived negatively by santri. The services of a peer boarding school have not yet been carried out optimally in accordance with the indicators of the success of pesantren peer counseling services. Increasing the existence of pesantren peer counselors needs to get serious attention in management management and improvement of pesantren-based peer counselors. It is hoped that by increasing the quality of pesantren peer counselors it will positively correlate with increasing santri trust, directly affecting the santri problem solving process.

Keywords: perception, existence, peer helper, pesantren

\section{Pendahuluan}

Pesantren sebagai salah satu pendidikan informal dan sekaligus di dalamnya juga terdapat pendidikan formal telah berfungsi sebagai pengembangan diri santri melalui berbagai sarana dan prasarana yang disediakan oleh pihak pondok pesantren. Pondok pesantren merupakan pendahulu dari sistem sekolah asrama (boarding school) yang telah lama diselenggarakan di dunia barat. Dibanding dengan system sekolah biasa, system pesantren memiliki banyak kelebihan, diantaranya peserta didik harus sit in di lingkungan pendidikan selama $24 \mathrm{jam}$, sehinga para pendidik dapat memberikan pengawasan, pembimbingan dan contoh nyata kepada peserta didi (santri) selama 24 jam. Di samping itu, penerapan suasana kekeluargaan di lingkungan pesantren yang dapat menciptakan suasana ramah dan hangat. Kondisi ini secara tidak langsung akan berimbas pada penanaman nilai-nilai pesantren, yaitu nilai-nilai kebersamaan, kemandirian dan kebebasan namun tetap penuh tanggungjawab. Sistem pesantren ini dimungkinkan akan dapat mencetak pribadi yang Tangguh dan berkarakter kuat. Pengembangan diri ini lebih penting dibandingkan dengan sekedar pemahaman tentang pengetahuan (Zarkasyi, 1998)

Pengembangan model layanan konseling sebaya pesantren dalam konsep ini dirumuskan beradasarkan teori konseling indigenious. Konseling indigeniuos ini merupakan penggabungan antara komponen dari budaya setempat dengan mendasarkan pada teori Ekologis dengan teori Medan social Kurt Lewin sebagai wadah kultur dan sub kultur (Brofenbrenner, 2005; Rudkin, 2003). Piranti budaya itu adalah suatu objek yang nilai-nilai budaya itu ditransmisikan (Rudkin, 2003). Pesantren memiliki sejumlah piranti budaya karena pesantren mengambil posisi sebagai subkultur komunitas. Keragaman corak budaya pesantren memiliki banyak ragam. Hal ini tergantung pada model dan system pembelajaran yang diterapkan di pesantren. Keragaman corak pesantren ini ditentukan oleh tujuan pesantren terhadap input yang akan dihasilkan. Beberapa ragam tujuan pesantren tersebut meliputi, pesantren salaf (hanya mengajarkan ilmu-ilmu agama saja), pesantren modern (menggunakan pendekatan formal tetapi juga menerapkan system salafiyah), dan pesantren kolaboratif (system pesantren dibangun dalam rangka pengembangan kolaboratif dengan masyarakat). (Wahid, 2001; A’la, Anisah, Aziz, \& Muhaimin, 2007).

Sistem relasional yang berkembang pada individu yang tinggal di pesantren merupakan manifestasi dari tradisi pesantren yang melingkarinya. Sistem ini diwariskan melalui teknik modeling. Proses pemodelan, penghayatan dalam organisasi, makna simbolisasi akan mentransformasi diri ke dalam diri santri hingga menjadi konsep diri. Transformasi diri akan budaya pesantren ini ditransmisikan melalui sistem pembelajaran, ritual dan pengamalan nilai-nilai agama, pengabdian dan pembiasaan yang lain, yang mengakar menjadi jati diri pesantren. Jati diri dan karakter pesantren ini menjadi dasar dalam mengembangkan konseling berbasis pesantren. (Hotifah, 2018)

Penyelenggaraan konseling sebagai cara untuk membimbing santri agar terentas dari permasalahannya masih belum memiliki bentuk yang sesuai dengan misi pembelajaran di pesantren itu sendiri. Selama ini jika ada santri yang memiliki masalah, alternatif solusinya langsung diarahkan ke ustadz, bahkan jika memang parah, maka langsung diarahkan ke kyainya langsung. Dari survey pra penelitian yang dilakukan penanganan masalah santri masih bersifat nasehat yang instruktif dan berdasarkan doktrin agama.

Hasil penelitian (Pritaningrum dan Hendriani, 2013) menunjukkan bahwa sebagian besar santri ketika menghadapi permasalahan, mereka tidak langsung mengutarakan kepada ustadz/kyainya, melainkan mereka lebih memilih menceritakan masalahnya kepada sesama santri. Para santri 
menganggap bahwa teman sesama santri merupakan pihak yang paling tepat untuk menceritakan masalahnya. Teman sesama santri dianggap lebih bisa memahami kondisinya, dan dalam upaya membantu penyelesaian masalahnya tidak menasehati/menggurui namun lebih pada upaya memberikan kesempatan mencurahkan semua yang dirasakannya (Hotifah, 2013). Para santri menyatakan bahwa bantuan yang diberikan oleh teman sesama santri efektif untuk meringankan beban permasalahan yang mereka hadapi. Kondisi ini berbeda dengan ketika mereka mengkonsultasikan masalah yang dihadapinya kepada ustadz ataupun kyai. Para santri merasa ada jarak yang terlalu jauh antara dirinya dengan ustadz/kyai, mereka merasa tidak bisa sepenuhnya menceritakan permasalahan dan perasaannya dengan bebas. Selain itu bantuan yang diberikan oleh ustadz/kyai yang cenderung berupa nasehat ataupun doadoa dianggap tidak terlalu membantu mereka, justru terkadang mereka merasa terbebani secara mental.

Kondisi-kondisi terkait kehidupan para santri dan permasalahan yang dihadapinya penting untuk ditemukan jalan keluarnya. Dikhawatirkan jika setiap permasalahan yang dihadapi oleh santri tidak pernah diselesaikan secara tuntas, maka hal ini akan mendorong santri untuk mencari pelampiasan/penyaluran beban yang dihadapinya. Penyimpangan perilaku akan sangat mungkin terjadi karena santri kebingungan tidak tahu harus bagaimana menyelesaikan masalah yang dihadapinya. Kasus-kasus santri kabur dari pesantren, santri melanggar aturan pesantren, dan sebagainya. Hal ini diindikasikan sebagai akibat akumulasi permasalahan yang tidak terselesaikan dengan baik. Disamping itu, derasnya arus informasi yang diterima remaja, sehingga membentuk mereka menjadi pribadi yang terbuka terhadap hal-hal yang baru (Makgosa, 2010).

Dalam hal ini, kepercayaan santri terhadap eksistensi penolong sebaya pesantren sangat urgen. Kepercayaan santri terhadap penolong sebaya yang membantunya akan menentukan keberhasilan proses konseling sebaya. Kepercayaan yang dimaksud adalah hubungan timbal balik antara konselor dan konseli. Hal ini ditentukan oleh penolong sebaya yang memiliki integritas, karakter dan kemampuan dalam teknik komunikasi konseling. Namun, jika kepercayaan santri rendah terhadap penolong sebaya, maka diperlukan waktu yang cukup lama untuk membangun kembali. (Sonnenberg dalam Robins, 1996). Oleh karena itu dibutuhkan penolong sebaya yang mendapatkan kepercayaan santri, agar konseling sebaya pesantren dapat berjalan dengan baik sesuai dengan tujuan konseling sebaya pesantren.

Namun kenyataannya, penolong sebaya pesantren masih dianggap sebagai teman sebaya yang belum memiliki kemampuan dalam membantu. Penolong sebaya masih diragukan keberadaannya. Bahkan sebagian besar santri masih meragukan kemampuan penolong sebaya dalam merahasiakan masalah yang akan diceritakan (wawancara dengan santri tahfidzul Qur'an, 2016)

Oleh karena peer helper adalah bukan konselor profesional dan diperankan oleh teman sebayanya, maka muncul pertanyaan apakah para santri dan konseli lainnya percaya terhadap kapasitas, kapabilitas, kredibilitas, kejujuran, ketulusan, dan ketahanan untuk memegang rahasia konseli yang terangkum dala sikap dan ketrampilan penolong sebaya pesantren). Berkenaan dengan hal tersebut, perlu segera dilakukan penelitian mendalam tentang eksistensi peer helper dalam membantu memecahkan permasalahan santri di lingkungan pesantren, sehingga akan segera diketahui posisi dan situasi psikologis santri dalam berinteraksi dengan penolong sebayanya.

Berdasarkan latar belakang permasalahan tersebut, maka peneliti ini meneliti tentang persepsi santri terhadap eksistensi penolong sebaya pesantren. Penelitian ini dilakukan dengan mengambil titik fokus persepsi santri terhadap eksistensi peer helper dalam memerankan konseling kepada teman sebayanya di lingkungan pesantren.

\section{Metode penelitian}

Penelitian ini menggunakan pendekatan kuantitatif diskriptif, dengan metode survey yang bertujuan untuk mengungkap dan menggambarkan situasi sebenarnya berdasarkan fakta yang terjadi di lapangan. Alasan peneliti menggunakan pendekatan survey adalah sesuai dengan tujuan penelitian, yaitu menjawab pertanyaan penelitian tentang bagaimana persepsi santri terhadap eksistensi penolong sebaya pesantren.

Populasi penelitian ini adalah santri pondok pesantren Hidayatul Mubtadiin Kanigoro Blitar dari berbagai jenjang MTs, MA, SMK dan Salafiyah Tahfidzul Qur'an sebanyak 861 santri. Teknik sampling yang digunakan adalah purposive sampling, yaitu dengan menentukan kreteria. Adapun kriteria sampel penelitian ini adalah 1) santri remaja berusia 13-18 tahun; 2) berpengalaman mendapatkan layanan 
konseling dari penolong sebaya 3) santri yang mukim di pesantren bukan santri «kalong». Jumlah santri yang terpilih menjadi sampel penelitian sebanyak 86 santri.

Penelitian ini dilakukan di Pondok Pesantren Hidayatul Mubtadiin Kanigoro Blitar Jawa Timur. Lokasi ini dipilih berdasarkan kompleksitas dan variasi permasalahan yang dialami santri, sehingga diharapkan akan mendapatkan hasil yang lengkap dan menyeluruh tentang berbagai masalah dan penyelesaiannya.

Pengumpulan data penelitian ini menggunakan skala sikap persepsi santri terhadap eksistensi penolong sebaya pesantren. Skala persepsi dikembangkan berdasarkan, definisi persepsi menurut Robbins (2003) adalah sebuah proses atau mengenali obyek dengan bantuan indera, dimana seseorang menerima stimulus dari luar dengan penuh kesadaran dan berusaha untuk memahami dan serta menginterpretasi stimulus tersebut menjadi sebuah makna. Dalam memahami stimulus tersebut melibatkan pada aspek kognitif, afektif dan psikomotorik. Atas dasar teoritik tersebut, skala persepsi santri terhadap eksistensi penolong sebaya dikembangkan. Adapun aspek yang dipersepsi adalah layanan konseling sebaya pesantren, sikap dan keterampilan penolong sebaya. Layanan penolong sebaya pesantren meliputi, relasi pembantuan secara individual (one to one helping profession), memimpin kelompok, memimpin dalam diskusi dan memeberikan alternative dalam mengambil keputusan dan pertimbangan. Sedangkan sikap dan ketrampilan penolong sebaya pesantren meliputi, sikap menghormati orang lain, obyektif dalam menyelesaikan masalah, kemampuan mengendalikan emosi, kemampuan menjaga rahasia orang lain, dan keterampilan komunikasi dalam konseling.

Jumlah item skala persepsi santri terhadap penolong sebaya pesantren sejumlah 35 item yang telah teruji validitas dan reliabilitasnya. Hasil uji validitas menggunakan product moment dengan mengkorelasikan skor item dan skor total, didapatkan nilai r 0,304-0,465. Perhitungan product moment ini dipilih karena data yang didapatkan berupa data interval. Menurut Azwar (2007) rentangan nilai r $>0,30$ masuk ketegori cukup valid. Sedangkan uji reliabilitasnya dengan alpha Cronbach sebesar 0,82, dengan kesimpulan cukup reliabel. Perhitungan skala persepsi ini menggunakan program software SPSS for MS Windows release 16.0.

Analisis data dalam penelitian ini menggunakan pendekatan analisis data kuantitatif diskriptif. Analisis data dalam penelitian ini menggunakan rumus prosentase. Adapun rumus penghitungannya didasarkan pada perhitungan frekuensi dibagi jumlah reponden di kalikan $100 \%$. Perhitungan ini digunakan untuk mengetahui prosentase persepsi santri terhadap eksistensi penolong sebaya di pesantren.

\section{Hasil Penelitian}

1. Gambaran Prosentase Responden

a) Gambaran prosentase persepsi sikap dan ketrampilan penolong sebaya berbasis pesantren

Untuk mengetahui persepsi santri terhadap sikap dan ketrampilan penolong sebaya berbasis pesantren, peneliti membagi menjadi tiga kategori (rendah, sedang, tinggi). Kategori ini menunjukkan klasifikasi persepsi santri terhadap sikap dan ketrampilan penolong sebaya berbasis pesantren. Berdasarkan pada distribusi normal, sebagaimana dijelaskan dalam gambar 1 berikut ini: 


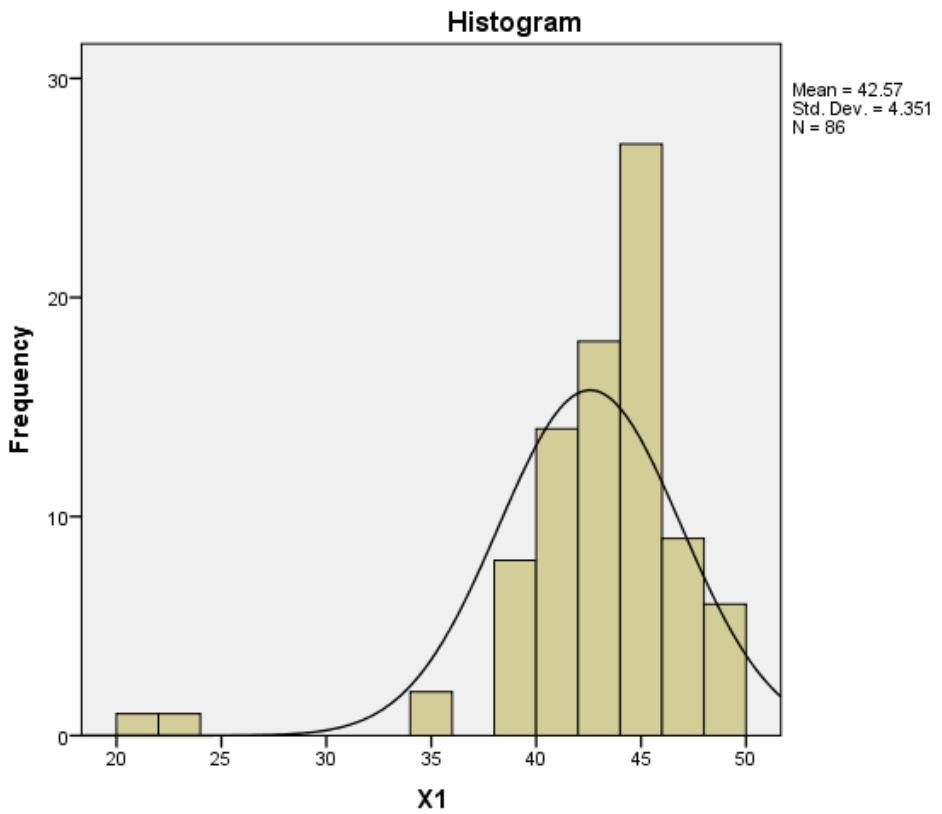

Gambar 1 Distribusi Frekuensi Persepsi Santri Terhadap Sikap dan Ketrampilan

Dari distribusi ini terlihat bahwa mean dari persepsi santri terhadap sikap dan ketrampilan penolong sebaya pesantren sebesar 42.57 dengan standart deviasi sebesar 4.35. Dari hasil ini bisa dilakukan pembagian menjadi tiga kategori, yaitu: rendah, sedang dan tinggi dengan mendasarkan pada perhitungan mean dan standart deviasi. Untuk mencari SD diperoleh dari perhitungan mean dan standart deviasi dengan pembagian sebagai berikut:

1. Skor untuk kategori rendah dimulai dari 0 sampai dengan X-SD $(42.57-4.35)=038.22$

2. Skor untuk kategori sedang dimulai dari X-1SD sampai dengan X + 1SD (42.57-4.35) s/d $(42.57+4.35)=38.22-46.92$

3. Kategori tinggi adalah skor-skor yang lebih besar dari 46.92

Berdasarkan kategorisasi distribusi ini maka, bisa dilakukan perhitungan frekuensi masingmasing kategori berdasarkan skor yang diperoleh, selengkapnya dapat dilihat pada tabel 1 berikut:

Tabel 1. Distribusi Tingkat Persepsi Santri Terhadap Sikap dan Ketrampilan

\begin{tabular}{cccc}
\hline Ketegori Persepsi & Kriteria & Frekuensi & Total (\%) \\
\hline Rendah & $0-38.22$ & 5 & 5.81 \\
Sedang & $38.5-46.92$ & 71 & 82.56 \\
Tinggi & $\geq 47$ & 10 & 11.63 \\
Total & & 86 & 100 \\
\hline
\end{tabular}

Dari hasil yang diperoleh diatas dapat dilihat bahwa tingkat persepsi santri terhadap sikap dan ketrampilan penolong sebaya berbasis pesantren yang tertinggi ada pada kategori kemampuan sedang, yang berarti, para santri mendapatkan layanan konseling sebaya rata-rata mempersepsi sikap dan ketrampilan penolong sebaya berbasis pesantren pada kategori sedang, hal ini ditunjukkan dengan skor sebesar 82.56. Skor $82.56 \%$ termasuk sangat tinggi dibandingkan dengan dua kategori lainnya yang hanya mendapat 5.81 kategori rendah, 11.63 untuk kategori tinggi.

Untuk lebih jelasnya distribusi persepsi santri terhadap sikap dan ketrampilan penolong sebaya berbasis pesantren tersebut dapat dilihat pada gambar 2 dibawah ini: 


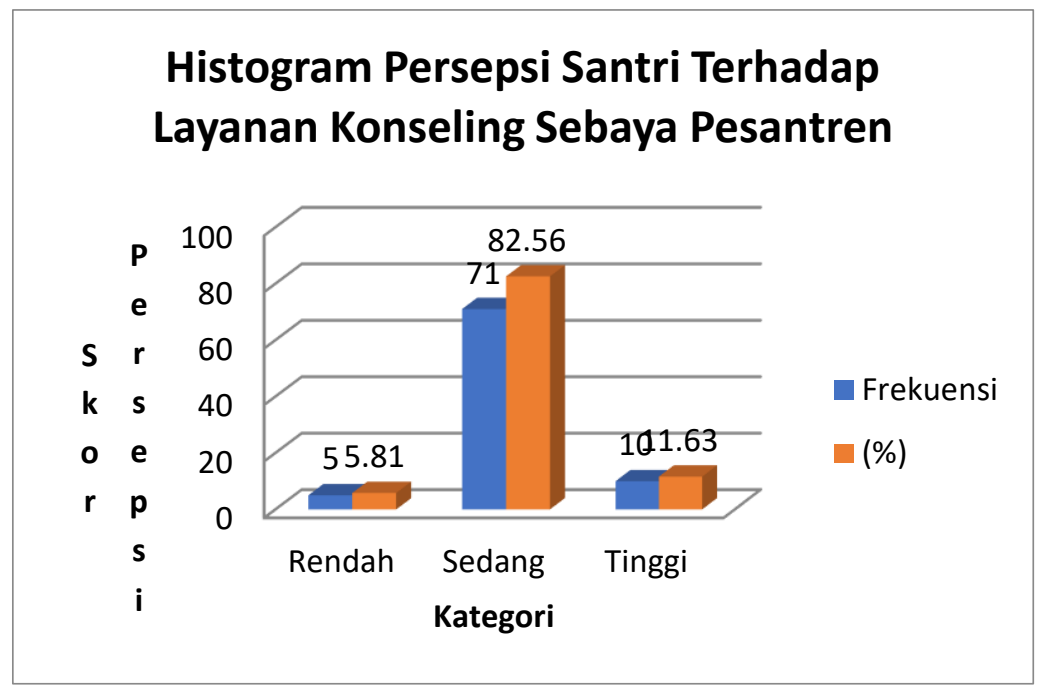

Gambar 2. Persepsi Santri Terhadap Layanan Konseling Sebaya Pesantren

b) Gambaran prosestase persepsi pelaksanaan konseling sebaya

Untuk mengetahui persepsi santri terhadap pelaksanaan konseling sebaya berbasis pesantren, peneliti membagi menjadi tiga kategori (rendah, sedang, tinggi). Kategori ini menunjukkan klasifikasi persepsi santri terhadap sikap dan ketrampilan penolong sebaya berbasis pesantren. Berdasarkan histogram, yang dijelaskan pada gambar 3 berikut ini:

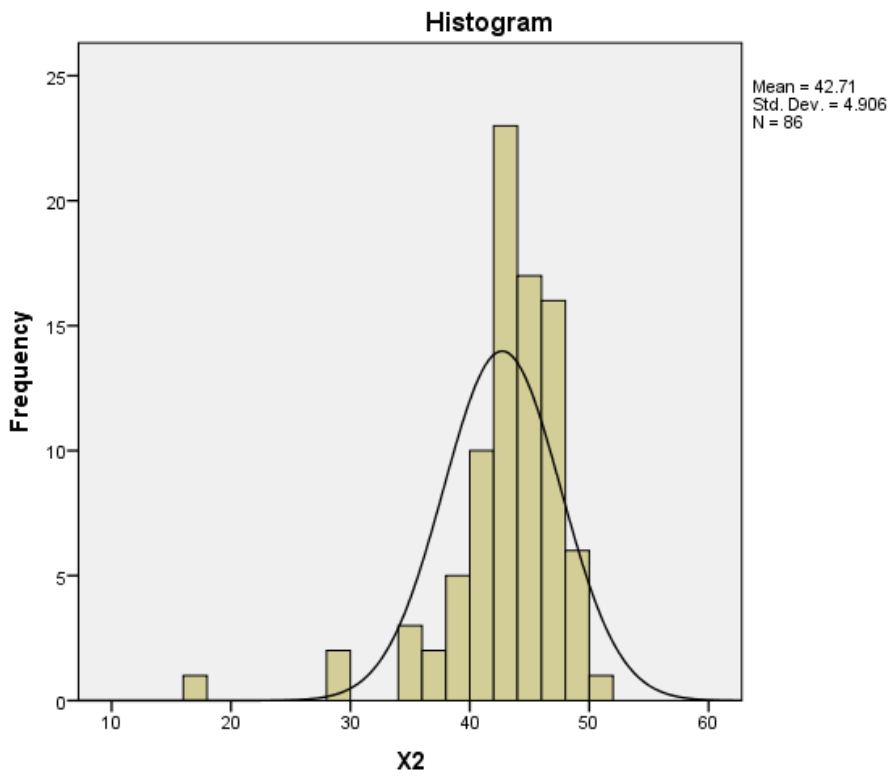

Gambar 3. Persepsi Santri Terhadap Pelaksanaan Konseling Sebaya Pesantren

Dari distribusi ini terlihat bahwa mean dari persepsi santri terhadap pelaksanaan konseling sebaya pesantren sebesar 42.71 dengan standart deviasi sebesar 4.906. Dari hasil ini bisa dilakukan pembagian menjadi tiga kategori, yaitu: rendah, sedang dan tinggi dengan mendasarkan pada perhitungan mean dan standart deviasi. Untuk mencari SD diperoleh dari mean dikurangi standart deviasi dengan pembagian sebagai berikut:

1. Skor untuk kategori rendah dimulai dari 0 sampai dengan X-SD $(0-37.804)$

2. Skor untuk kategori sedang dimulai dari X-1SD sampai dengan X + 1SD (37.804-47.62)

3. Skor untuk kategori tinggi adalah skor-skor yang lebih besar dari 48 
Berdasarkan perhitungan klasifikasi tersebut di atas maka, dilakukan perhitungan frekuensi masing-masing kategori. Sebagai gambaran visualisasi dapat dipaparkan pada tabel 2 berikut:

Tabel 2. Distribusi Tingkat Persepsi Santri Terhadap Layanan Konseling Sebaya

\begin{tabular}{cccc}
\hline Ketegori Persepsi & Kriteria & Frekuensi & Total (\%) \\
\hline Rendah & $0-37.804$ & 11 & 12.79 \\
Sedang & $38-47.62$ & 68 & 79.07 \\
Tinggi & $\geq 48$ & 7 & 8.14 \\
Total & & 86 & 100 \\
\hline
\end{tabular}

Dari hasil yang diperoleh diatas dapat dilihat bahwa tingkat persepsi santri terhadap pelaksanaan konseling sebaya berbasis pesantren yang tertinggi ada pada kategori kemampuan sedang, yang berarti, para santri mendapatkan layanan konseling sebaya rata-rata mempersepsi sikap dan ketrampilan penolong sebaya berbasis pesantren pada kategori sedang sebesar 79.07\%. Skor 79.07\% termasuk sangat tinggi dibandingkan dengan dua kategori lainnya yang hanya mendapat 12.79 kategori rendah, 8.14 untuk kategori tinggi.

Untuk lebih jelasnya distribusi persepsi santri terhadap pelaksanaan konseling sebaya berbasis pesantren tersebut dipaparkan pada gambar 4 dibawah ini:

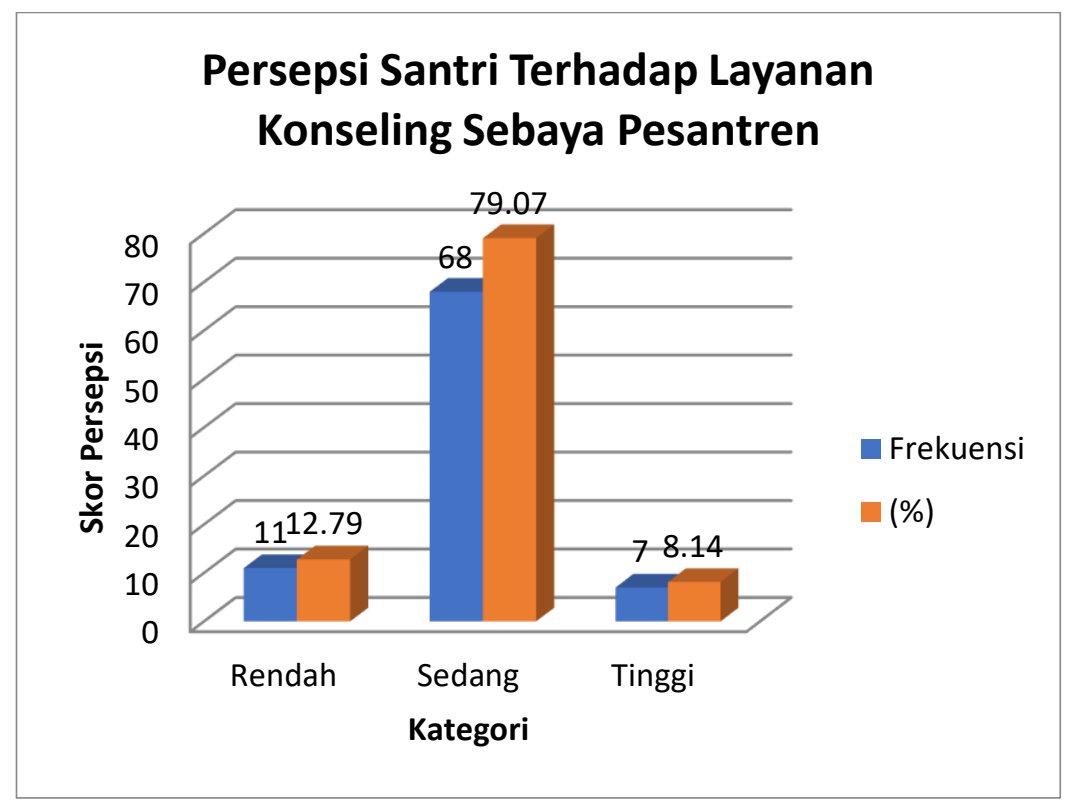

Gambar 4. Histogram Persepsi Santri Terhadap Layanan Konseling Sebaya Pesantren

c) Gambaran prosentase persepsi dukungan sistem dalam pelaksanaan konseling sebaya pesantren

Untuk mengetahui persepsi santri terhadap dukungan sistem pelaksanaan konseling sebaya berbasis pesantren, peneliti membagi menjadi tiga kategori (rendah, sedang, tinggi). Kategori ini menunjukkan klasifikasi persepsi santri terhadap dukungan sistem pelaksanaan konseling sebaya berbasis pesantren berbasis pesantren. Gambaran lain, dipaparkan pada gambar 5 berikut ini: 


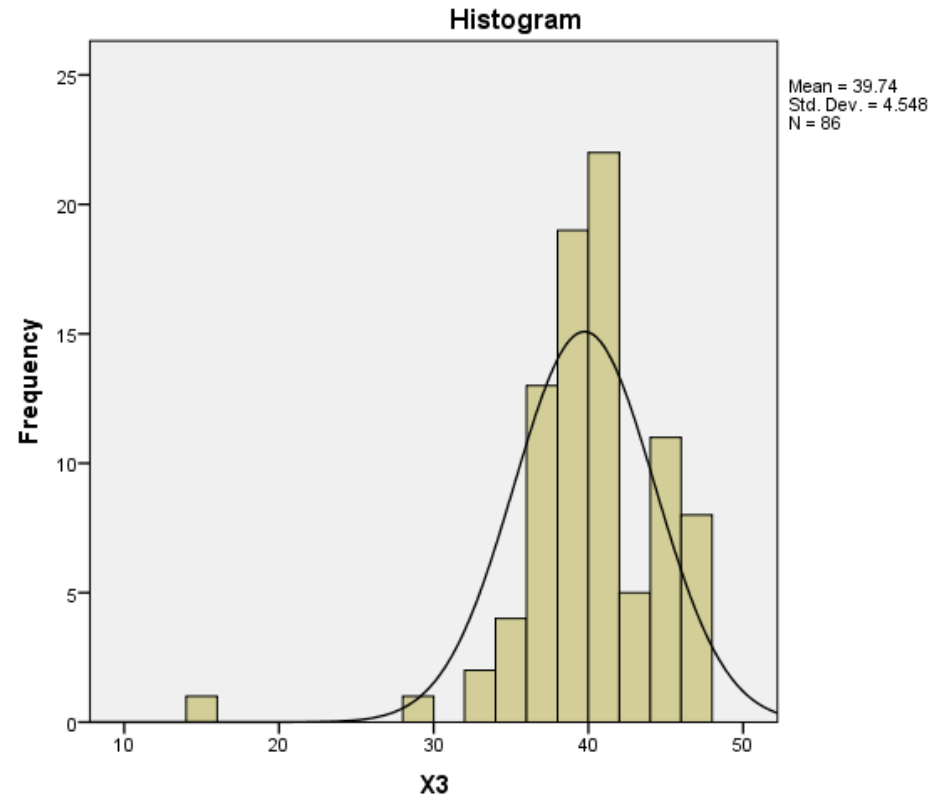

Gambar 5. Persepsi Santri Terhadap Dukungan sistem Pelaksanaan Konseling Sebaya

Dari distribusi ini terlihat bahwa mean dari persepsi santri terhadap dukungan pelaksanaan konseling sebaya pesantren sebesar 39.74 dengan standart deviasi sebesar 4.548. Dari hasil ini bisa dilakukan pembagian menjadi tiga kategori, yaitu: rendah, sedang dan tinggi dengan mendasarkan pada perhitungan mean dan standart deviasi. Untuk mencari SD diperoleh dari mean dikurangi standart deviasi dengan pembagian sebagai berikut:

1. Skor untuk kategori rendah dimulai dari 0 sampai dengan X-SD $(0-35.192)$

2. Skor untuk kategori sedang dimulai dari X-1SD sampai dengan X + 1SD (35.192 44.288)

3. Skor untuk kategori tinggi adalah skor-skor yang lebih besar dari 44.288

Berdasarkan distribusi ini maka, bisa dilakukan perhitungan frekuensi masing-masing kategori berdasarkan skor yang diperoleh, selengkapnya dapat dilihat pada tabel 3 berikut:

Tabel 3. Distribusi Tingkat Persepsi Santri Terhadap Dukungan sistem Pelaksanaan Konseling Sebaya

\begin{tabular}{cccc}
\hline Ketegori Persepsi & Kriteria & Frekuensi & Total (\%) \\
\hline Rendah & $0-35.192$ & 7 & 8.14 \\
Sedang & $35.5-44.288$ & 64 & 74.42 \\
Tinggi & $\geq 45$ & 15 & 17.44 \\
Total & & 86 & 100 \\
\hline
\end{tabular}

Dari hasil yang diperoleh diatas dapat dilihat bahwa tingkat persepsi santri terhadap dukungan sistem pelaksanaan konseling sebaya sikap dan ketrampilan penolong sebaya berbasis pesantren yang tertinggi ada pada kategori kemampuan sedang, yang berarti, para santri mendapatkan layanan konseling sebaya rata-rata mempersepsi sikap dan ketrampilan penolong sebaya berbasis pesantren pada kategori sedang, hal ini ditunjukkan dengan skor sebesar $74.42 \%$. skor $74.42 \%$ termasuk sangat tinggi dibandingkan dengan dua kategori lainnya yang hanya mendapat 8.14 kategori rendah, 17.44 untuk kategori tinggi.

Untuk lebih jelasnya distribusi persepsi santri terhadap sikap dan ketrampilan penolong sebaya berbasis pesantren tersebut dapat dilihat pada gambar 6 dibawah ini: 


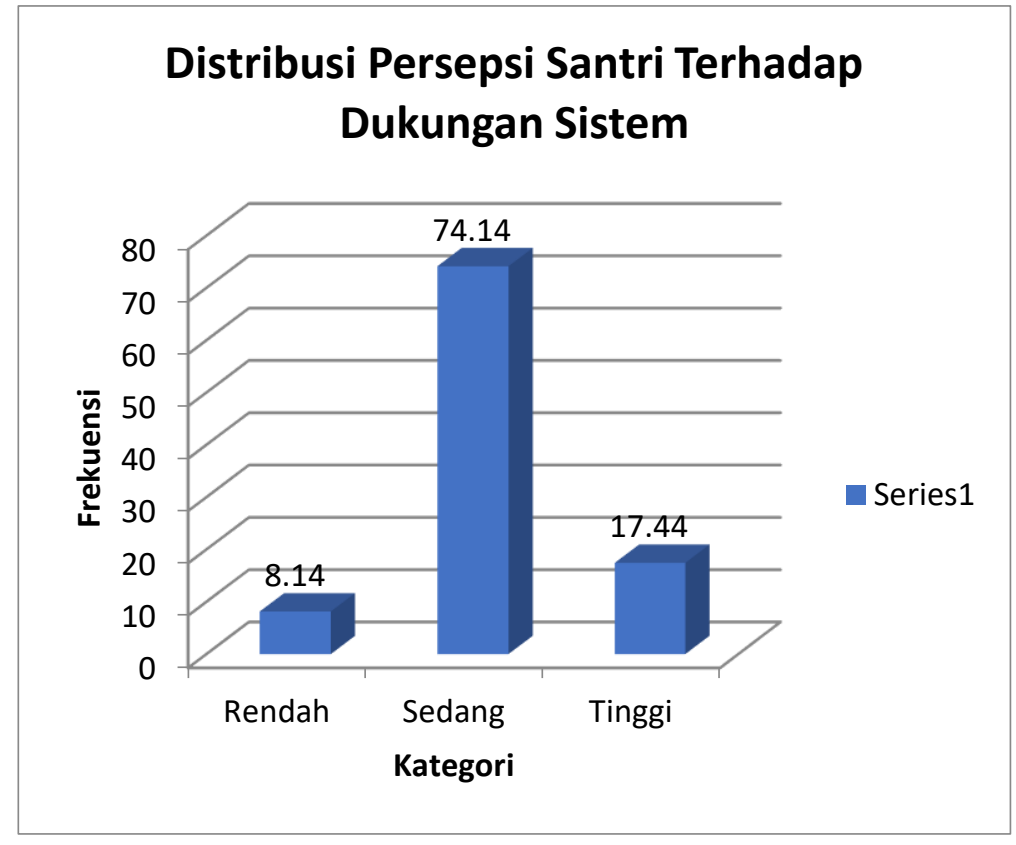

Gambar 6. Distribusi Frekuensi Persepsi Santri Terhadap Dukungan Sistem

\section{Pembahasan}

Eksistensi penolong sebaya di pondok pesantren menjadi hal yang sangat vital dalam penyelesaian kasus atau masalah yang dihadapi santri. Secara empiris terbukti bahwa kehadiran penolong sebaya di pondok pesantren memiliki urgensi dan keberterimaan di kalangan santri. Sebagaimana perkembangan sosial pada remaja lebih melibatkan kelompok teman sebaya dibandingkan orang tua (Conger, 1991; Papalia \& Olds, 2011). Dalam konteks kehidupan santri di Pesantren, teman sebaya merupakan rujukan pertama bagi remaja santri, baik untuk berbagai kebahagiaan maupun kesedihan.

Pesantren memiliki beberapa elemen dalam membantu memecahkan permasalahan santri diantaranya, Kyai, ustadz dan Ustadzah, serta Murabbi. Namun tidak dimanfaatkan olen santri secara maksimal dengan alasan ada rasa sungkan dan canggung ketika ingin berbagi permasalahannya. Santri merasa ada gap yang cukup jauh antara dirinya dengan Ustadz/ah (Hotifah, 2014). Dengan begitu, peran teman sebaya bagi remaja santri cukup besar.

Sebagian santri telah memposisikan dirinya sebagai penolong teman sebayanya. Beberapa pesantren juga telah membentuk kelompok penolong sebaya berbasis pesantren, termasuk pesantren Hidayatul Mubatdiin. Kehadiran penolong sebaya berbasis pesantren juga mendapatkan tanggapan positif di kalangan santri, namun dalam implementasinya masih perlu mendapatkan dukungan untuk pengembangan layanan penolong sebaya di pesantren.

Persepsi santri terhadap sikap dan keterampilan penolong sebaya serta layanan konseling sebaya dalam kategori cukup. Kondisi menunjukkan bahwa tingkat kepercayaan penolong sebaya dalam memberikan layanan pembantuan masih perlu ditingkatkan. Persepsi santri positif terhadap pelaksanaan penolong sebaya lebih didasari oleh pengalaman santri tentang kompleksitas dan penyelesaian masalah yang bersifat sentralistik oleh ustadz/ustandzah dan seluruh jajarannya yang cenderung bersifat instruktif dan indoktrinatif. Dalam posisi seperti ini, kehadiran dan peran penolong sebaya yang lebih bersifat humanistik dan dialogis dengan prinsip kesebayaan diangap sebagai aktivitas yang menyenangkan. Kedekatan dan kesamaan pandang dalam menyikapi setiap masalah menjadikan penolong sebaya di pondok pesantren sebagai agen perubahan sikap santri yang sangat solutif dan adaptif terhadap situasi lingkungan pesantren.

Dalam kajian psikologis, persepsi seseorang terhadap objek sikap biasanya dimunculkan dalam bentuk respon ungkapan kata (verbal expression) dan tingkah laku nyata (overt behavior). Ungkapan kata bisa berbentuk pendapat-pendapat mengenai objek dan ungkapan perasaan senang dan tidak senang (emotion) dalam menghadapi objek sikap (Lefton, 1979). Respon ungkapan kata dalam praktiknya pada diri individu selalu berangkaian dan sulit dipisahkan dengan respon tingkah laku. Biasanya respon yang 
berbentuk ungkapan perasaan dan uangkapan pendapat akan mendasari terbentuknya dan terlaksananya respon tingkah laku. Namun demikian, ada pula munculnya respon tingkah laku tanpa didasari oleh ungkapan perasaan dan pendapat (persepsi) yang positif, sehingga respon yang demikian itu biasanya tidak bertahan lama dan mudah menimbulkan rasa frustrasi dan bosan dalam mengahadpi objek sikap.

Kajian tentang persepsi pasti akan selalu terkait dengan kajian sikap karena memang persepsi merupakan bagian dari sikap. Lambert \& Lambert mengetengahkan tiga komponen sikap yaitu cara berpikir, cara merasakan dan cara mereaksi. An attitude isi an organized and concistent manner of thinking, feeling, and reacting with regard to people, groups, social issues, or more generally, eny event in one's environment (Lambert \& Lambert, 1964;50). Ketiga komponen tersebut merupakan komponen yang paling mendasar yang berhubungan dengan pikiran dan keyakinan seseorang, persepsi-persepsinya dan pendapat-pendapatnya terhadao objek yang dihadapi.

Terkait dengan respon sikap yang berupa persepsi santri terhadap eksistensi penolong sebaya, dapat diungkapkan bahwa, penolong sebaya harus mampu memberikan pengaruh yang kuat terhadap penyelesaian masalah santri dengan berupaya menampilkan dirinya sebagai pribadi yang menarik, berpengetahuan, berempati dan bersimpati terhadap santri agar mereka mendapat persepsi positif. Persepsi positif akan berlanjut pada perubahan pemahaman ke arah positif dan selanjutnya akan diikuti oleh perubahan perilaku yang positif pula di kalangan santri. Santri harus memiliki persepsi, pendapat dan fikiran yang positif terhadap eksistensi penolong sebaya, sehingga peran yang dilakukan penolong sebaya dalam memabantu menyelesaikan masalah mendapat kepercayaan yang tinggi dari pihak santri.

Oleh karena begitu kuatnya posisi penolong sebaya sebagai objek sikap (agen pembaharu) terhadap perubahan dan penyelesaian masalah yang dihadapi santri, maka kapasistas, kredibilitas dan integritas penolong sebaya perlu dibangun sebaik mungkin, baik dalam tataran penampilan pisik maupun kekuatan kepribadiannya, sehingga penolong sebaya akan menjadi role model di kalangan santri. Oleh karena itu, dalam penelitian ini masih perlu diungkap lebih jauh lagi tentang tanggapan atau pandangan santri terhadap "penolong sebaya ideal" yang diidamkan oleh santri dan seluruh komunitas pesantren. Penolong sebaya ideal menjadi sangat mendesak untuk segera dilakukan penelitian, karena posisi dan peran penolong sebaya yang memang bukan sebagai konselor profesional, sehingga akan diperoleh postur penolong sebaya khas untuk kalangan pondok pesantren yang memang memiliki ke-khas-an juga.

Terkait dengan hasil-hasil penelitian ini, sangat wajar jika persepsi santri terhadap keberadaan penolong sebaya masih dalam kategori sedang. Hal ini bukan berarti persepsi santri terhadap penolong sebaya tidak positif, tetapi lebih pada pemberian gambaran bahwa peran dan kapasitas serta kredibilitas penolong sebaya memiliki potensi besar untuk ditingkatkan agar dapat menjadi penolong yang efektif dengan tetap memperhatikan prinsip-prinsip perbantuan yang didasarkan atas kesebayaan dan kesamaan tanggungjawab.

\section{Kesimpulan}

Kepercayaan santri terhadap sikap dan keterampilan penolong sebaya berada dalam kategori sedang. Hal ini menunjukkan bahwa untuk membangun kepercayaan santri terhadap penolong sebaya pesantren, perlu adanya strategi peningkayan kualitas penolong sebaya pesantren. Dengan mengingkatnya kualitas sikap dan keterampilan penolong sebaya pesantren, maka secara signifikan santri membangun image yang posisit dan secara linier akan meningkatkan kepercayaannya

Persepsi santri terhadap kualitas layanan penolong sebaya pesantren juga masih perlu ditingkatkan. Layanan konseling sebaya pesantren berbanding lurus dengan sikap dan keterampilan yang dimiliki oleh penolong sebaya pesantren. Dengan meningkatkan kualitas pribadi penolong sebaya pesantren dan layanan konseling sebaya pesantren, maka diharapkan penyelesaian permasalahan santri dapat dipecahnya secara optimal.

\section{Ucapan Terima Kasih}

Terima kasih kepada Fakultas Ilmu Pendidikan Universitas Negeri Malang yang telah memberikan kesempatan kepada penulis untuk melakukan penelitian melalui alokasi dana PNBP. 


\section{Daftar Pustaka}

A'la, A., Anisah, H., Azis, A., \& Muhaimin, A. (2007). Praksis Pembelajaran Pesantren. Yogyakarta: Yayasan Selasih dan Forum Pesantren.

Azwar, Saifuddin. (2007) Validitas dan Reliabilitas. Pustaka Pelajar: Yogyakarta

Bronfenbrenner, U. (2005) Making Human Beings Human Bioecological Perspectives on Human Development. California: Sage Publication.

Chirzin, M.H. (2007). Pesantren Selalu Tumbuh dan Berkembang. In N. M.D, A.A'la, H. Anisah, A. Azis, \& A. Muhaimin, Praksis Pembelajaran Pesantren (pp.vii-x). Yogyakarta: Forum Pesantren dan Yayasan Selasih.

Cohen R, Swerdlik M. (2010). Psychological testing and assessment. Boston: McGraw-Hill Higher Education

Conger, J.J. (1991) Adolescence and Youth; Psychological Development in aa Changing world. $4^{\text {th }}$ edition. New York: haper Collin Publishers.

Cronbach, L.J. (1984). Essential of Psychological Testing. Fourth Edition. New York: Harper and Row Publisher, Inc.

Hotifah, Yuliati. (2010). Kesehatan Mental Santri dan Terapinya Menurut Islam. Jurnal Egalita; Jurnal kesetaraan dan Keadilan Gender. Vol V Nomer 1 Tahun 2010.

Hotifah, Yuliati. (2013). Pengembangan Model Penolong Sebaya Berbasis Kearifan Lokal Pesantren di Jawa Timur. Laporan Penelitian DP2M Universitas Negeri Malang. Tidak diterbitkan.

Hotifah, Yuliati. (2017) Peer Counseling in Pesantren Perspective. Journal of Social Sciences. Ces\&RJJSS. Volume 6 Number 2 April 2017.

Hotifah, Yuliati. (2018) Konseling Sebaya Pesantren. Drean Litera Buana:Malang

Djumransyah, H.M. (2001) Pendidikan Pesantren dan Kemandirian Santri. Jurnal Ilmu Pendidikan. Vol 8. No. 2 (2001). E-ISSN:2442-8655. ISSN: 0215-9643.

Lambert, William W \& Lambert Wallace E. (1964). Social Psychology. New Jersey: Printice Hall, Inc.

Lefton, Lester A. , (1979). Psychology. Boston: Allyn and Bacon, Inc.

Muhakamurrahman, Ahmad. Pesantren: Santri, Kiai, dan Tradisi. Ibda’: Jurnal Kebudayaan Islam. Vol 12. No. 2, Juli-Desember 2014. ISSN : $1693-6736$

Nashori, Fuad. (2011) Kekuatan Karakter Santri. Jurnal Millah Vol. XI No. 1 Agustus 2011.

Rudkin, J. (2003). Community Psychology Guiding Principles and Orienting Concepts. New Jersey: Prentice Hall.

Papalia, D.E., Old, S.W., Feldman, \& R.D. (12008). Human Development (terjemahan A.K> Anwar) Jakarta: Prenada Media Group. 
Suwarno. (2017) Pondok Pesantren dan Pembentukan Karakter Santri (Studi tentang Pengembangan Potensi-Potensi Kepribadian Peserta Didik Pondok Pesantren Terpadu Almultazam Kabupaten Kuningan). Oasis: Jurnal Ilmiah Kajian Islam. Vol 2. No 1 Agustus 2017.

Zarkasyi, Amal F., (1998) Pondok Pesantren sebagai Lembaga Pendidikan dan Dakwah. Jakarta: GIP 